\title{
Deductive conflict frame (War Coverage)
}

\section{AUTHOR}

Marc Jungblut

\section{KEYWORDS}

war coverage, frame, textual frame

\section{BRIEF DESCRIPTION}

This variable describes how a war is framed in a news article. It suggests what interpretation or perspective on a war is promoted through a news item (Dimitrova \& Strömbäck, 2008; Entman, 1993). In general, there are two approaches to framing: Deductive frame analyses measure the presence of frames that were derived from prior research or small pilot studies, whereas inductive frame analyses derive the frames from the actual material itself. As such, the frames measured in inductive analyses tend to be case-specific and can rarely be used for other conflict cases and material (cf. Matthes \& Kohring, 2008). In deductive frame analyses, however, a set re-occurring frames has been identified and operationalized. They have been measured in the coverage of a variety of wars and in news items that were published in different media organizations (e.g. Carpenter, 2007; Dimitrova \& Strömbäck, 2005, 2008). These frames and their operationalizations will be described in the following example.

FIELD OF APPLICATION/THEORETICAL FOUNDATION Frame analyses is grounded in the framing approach that describes a media frame as the result of a journalistic process of selecting some aspects of a given social reality and making them more salient in a given text (Entman, 1993). As such, framing is often measured to analyze how a war is portrayed in the news. In doing so, scholars mainly aim to identify media bias that for example can be the result of ethnocentrism, the editorial line, political influences or the predominant journalism culture (Baden, 2014; Jungblut, 2020; Shoemaker \& Reese, 2014). Consequentially, media frames are often regarded as the result of a specific working environment and are thus often conceptualized as a dependent variable (e.g. Carpenter, 2007; Dimitrova, 2006; Dimitrova \& Strömbäck, 2005, 2008). Alternatively, media frames can be understood as the independent variable if a study seeks to unravel whether the media holds an impact on the public opinion on a given war (e.g. Edy \& Meirick, 2007).

\section{REFERENCES/COMBINATION WITH OTHER METHODS OF DATA COLLECTION}

Frames that have repeatedly been identified in content analytical research have also been used in experimental research designs to unravel if the media portrayal of a war shapes how the audience thinks about this particular war (e.g. Iyengar \& Simon, 1993). Similarly, scholars have also combined content analyses with multiple waves of surveys to analyze whether the media, for example, influences the public support for conflict interventions (e.g. Edy \& Meirick, 2007). 


\section{SAMPLE OPERATIONALIZATION}

Please indicate which of these frames is present in the text. In each article, multiple frames can be present at the same time (Dimitrova \& Strömbäck, 2005). See Table 1.

\begin{tabular}{|c|c|c|}
\hline Frame & Description & Measurement \\
\hline Military Conflict Frame & $\begin{array}{l}\text { There is an emphasis on the military } \\
\text { conflict/action among individuals, } \\
\text { groups, or institutions }\end{array}$ & $\begin{array}{l}0=\text { frame is absent } \\
1=\text { frame is present }\end{array}$ \\
\hline Human Interest Frame & $\begin{array}{l}\text { There is an emphasis on the human } \\
\text { participants in the event }\end{array}$ & $\begin{array}{l}0=\text { frame is absent } \\
1=\text { frame is present }\end{array}$ \\
\hline Violence of War Frame & $\begin{array}{l}\text { There is an emphasis on injuries/cau- } \\
\text { salities and the destruction or after- } \\
\text { math caused by war }\end{array}$ & $\begin{array}{l}0=\text { frame is absent } \\
1=\text { frame is present }\end{array}$ \\
\hline Anti-War Protest Frame & $\begin{array}{l}\text { There is an emphasis on the opposi- } \\
\text { tion to war }\end{array}$ & $\begin{array}{l}0=\text { frame is absent } \\
1=\text { frame is present }\end{array}$ \\
\hline Media Self-Reference Frame & $\begin{array}{l}\text { There is an emphasis on the news me- } \\
\text { dia and their reporting of war }\end{array}$ & $\begin{array}{l}0=\text { frame is absent } \\
1=\text { frame is present }\end{array}$ \\
\hline Responsibility Frame & $\begin{array}{l}\text { There is an emphasis on the par-ty/ } \\
\text { person responsible for the event, } \\
\text { issue, or problem }\end{array}$ & $\begin{array}{l}0=\text { frame is absent } \\
1=\text { frame is present }\end{array}$ \\
\hline Diagnostic Frame & $\begin{array}{l}\text { There is an emphasis on what caused } \\
\text { the event or problem }\end{array}$ & $\begin{array}{l}0=\text { frame is absent } \\
1=\text { frame is present }\end{array}$ \\
\hline Prognostic Frame & $\begin{array}{l}\text { There is an emphasis on the possible } \\
\text { consequences of the event }\end{array}$ & $\begin{array}{l}0=\text { frame is absent } \\
1=\text { frame is present }\end{array}$ \\
\hline
\end{tabular}

\section{INFORMATION ON CARPENTER, 2007}

Author: Serena Carpenter

Research question/research interest: Portrayal of the Iraq War in Elite and Non-Elite newspapers

Object of analysis: Two elite newspapers (New York Times \& Washington Post) and four nonelite newspapers (San Antonio Express News, Roanoke Times, News Tribune and Columbus Dispatch)
Timeframe of analysis: The study analyzes the framing in three phases: Invasion Phase (March 20, 2003, to May 1, 2003), final two months of the presidential campaign (September 1, 2004, to November 2,2004) \& period from the first Iraqi election to the Iraqi National Assembly's vote to approve a cabinet (January 30, 2005, to April 28, 2005) 
INFORMATION ON DIMITROVA \& STRÖMBÄCK, 2005

Author: Daniela V. Dimitrova, Jesper Strömbäck Research question/research interest: Framing of the Iraq War in the Elite Newspapers in Sweden and the United States

Object of analysis: Dagens Nyheter (Sweden) and The New York Times (United States)

Timeframe of analysis: The study analyzes the framing during the invasion of Iraq (March 20, 2003, to May 1, 2003)

\section{INFO ABOUT VARIABLE}

Variable name/definition: Deductive conflict frame

\section{Level of analysis: Article}

Values: 0 = absent, $1=$ present (for each of the described frames)

Scale: binary (nominal)

Reliability: Scott's pi $>0.86$

\section{REFERENCES}

Baden, C. (2014). Constructions of violent conflict in public discourse. Conceptual framework for the content \& discourse analytic perspective (within WP5, WP6, WP7, \& WP8). INFOCORE Working Paper 2014/10. http://www.infocore. eu/wp-content/uploads/2016/02/Conceptual-Paper-MWG-CA_final.pdf

Carpenter, S. (2007). US elite and non-elite newspapers' portrayal of the Iraq War: A comparison of frames and source use. Journalism \& Mass Communication Quarterly, 84(4), 761-776. doi:10.1177/107769900708400407

Dimitrova, D. V. (2006). Episodic frames dominate early coverage of Iraq War in the NYTimes.com. Newspaper Research Journal, 27(4), 79-83. https://doi. org/10.1177/073953290602700406

Dimitrova, D. V., \& Strömbäck, J. (2005). Mission accomplished? Framing of the Iraq War in the elite newspapers in Sweden and the United States. International Communication Gazette, 67(5), 399-417. https:// doi.org/10.1177/0016549205056050

Dimitrova, D. V., \& Strömbäck, J. (2008). Foreign policy and the framing of the 2003 Iraq War in elite Swedish and US newspapers. Media, War \& Conflict, 1(2), 203-220. doi:10.1177/1750635208090957

Edy, J. A., \& Meirick, P. C. (2007). Wanted, dead or alive: Media frames, frame adoption, and support for the war in Afghanistan. Journal of Communication, 57(1), 119-141. doi:10.1111/j.1460-2466.2006.00332_4.x

Entman, R. M. (1993). Framing: Toward clarification of a fractured paradigm. Journal of Communication, 43(4), 51-58. doi:10.1111/j.1460-2466.1993.tb01304.x

Iyengar, S., \& Simon, A. (1993). News coverage of the Gulf crisis and public opinion: A study of agenda-setting, priming, and framing. Communication research, 20(3), 365-383. doi:10.1177/009365093020003002

Jungblut, M. (2020). Strategic Communication and its Role in Conflict News: A Computational Analysis of the International News Coverage on Four Conflicts. Springer Nature.

Matthes, J., \& Kohring, M. (2008). The content analysis of media frames: Toward improving reliability and validity. Journal of Communication, 58(2), 258-279. doi:10.1111/j.1460-2466.2008.00384.x

Shoemaker, P. J., \& Reese, S. D. (2014). Mediating the message in the 21st century: a media sociology perspective (Third edition. ed.). Routledge.

Scale: binary (nominal)

Reliability: Holsti > .88 (Dimitrova \& Strömbäck, 2005) - Scott's pi > 0.86 (Carpenter, 2007)

\section{REFERENCES}

Baden, C. (2014). Constructions of violent conflict in public discourse. Conceptual framework for the content \& discourse analytic perspective (within WP5, WP6, WP7, \& WP8). INFOCORE Working Paper 2014/10. http://www.infocore. eu/wp-content/uploads/2016/02/Conceptual-Paper-MWG-CA_final.pdf

Carpenter, S. (2007). US elite and non-elite newspapers' portrayal of the Iraq War: A comparison of frames and source use. Journalism \& Mass Communication Quarterly, 84(4), 761-776. doi:10.1177/107769900708400407

Dimitrova, D. V. (2006). Episodic frames dominate early coverage of Iraq War in the NYTimes.com. Newspaper Research Journal, 27(4), 79-83. https://doi. org/10.1177/073953290602700406

Dimitrova, D. V., \& Strömbäck, J. (2005). Mis- 
sion accomplished? Framing of the Iraq War in the elite newspapers in Sweden and the United States. International Communication Gazette, 67(5), 399-417. https:// doi.org/10.1177/0016549205056050

Dimitrova, D. V., \& Strömbäck, J. (2008). Foreign policy and the framing of the 2003 Iraq War in elite Swedish and US newspapers. Media, War \& Conflict, 1(2), 203-220. doi:10.1177/1750635208090957

Edy, J. A., \& Meirick, P. C. (2007). Wanted, dead or alive: Media frames, frame adoption, and support for the war in Afghanistan. Journal of Communication, 57(1), 119-141. doi:10.1111/j.1460-2466.2006.00332_4.x

Entman, R. M. (1993). Framing: Toward clarification of a fractured paradigm. Journal of Communication, 43(4), 51-58. doi:10.1111/j.1460-2466.1993.tb01304.x

Iyengar, S., \& Simon, A. (1993). News coverage of the Gulf crisis and public opinion: A study of agenda-setting, priming, and framing. Communication research, 20(3), 365-383. doi:10.1177/009365093020003002

Jungblut, M. (2020). Strategic Communication and its Role in Conflict News: A Computational Analysis of the International News Coverage on Four Conflicts. Springer Nature.

Matthes, J., \& Kohring, M. (2008). The content analysis of media frames: Toward improving reliability and validity. Journal of Communication, 58(2), 258-279. doi:10.1111/j.1460-2466.2008.00384.x

Shoemaker, P. J., \& Reese, S. D. (2014). Mediating the message in the 21st century: a media sociology perspective (Third edition. ed.). Routledge. 